\title{
A Discussion about the Institutionalization of Postmodernism in Postmodern Studies
}

\author{
Yue-ping WANG \\ Basic Dpt., Zhengzhou University of Science \& Technology, Zhengzhou 450000, \\ China
}

234571@qq.com

Keywords: Postmodernism, Politics, Institutionalization.

\begin{abstract}
This paper focuses on the new trends of postmodern studies and practices. In her opinion, postmodernism has not been dead as some theorists declared, only that it has entered into a new phase which can be temporarily called "the late postmodern moment," that is, postmodernism has evolved into an institutionalized and canonized counter-discourse, widely adopted and applied in contemporary cultural practices, artistic creativities, as well as academic and pedagogic studies. This paper also covers other topics, such as the influence of digital information technology upon postmodernism, the historical background of the growing-up of historiographic metafiction, and the similarities and differences between postmodern politics and that of Marxism, feminism and post-colonialism.
\end{abstract}

\section{Introduction:}

Chinese researchers began to know you in the early 1990s. Since then, you have become a key postmodern thinker for Chinese scholars. As you know, four of your books have been translated into Chinese so far, all of which are studied earnestly while inspiring effectively our postmodern researches. A lot of journal articles and several doctorial dissertations have been published concentrating on your theories about irony, parody, narcissistic narrative, historiographic metafiction in particular and postmodernism in general. It is really interesting, however, to note the fact that since the late 1990s, Western theorists have been eager to announce the unduly death of postmodernism and even the death of theory, while post-modernism only began to be an eye-catching buzzword exactly at the same time both in the field of academic research and artistic creation. What do you think about the so-called "death of postmodernism," and is that the reason for you to divert your focus of study to the multidisciplinary study of opera, disease and cultural history in the late 1990s? If postmodernism has really been dead, then what could be the suspected terminator, the 9/11 terrorist attack, the world financial crisis, or the digital technology as was claimed by Alan Kirby?

\section{Various Discussions about Postmodernism}

Not only the definition of postmodernism but its very history has come to be highly contested over the last three or four decades. As you say, postmodernism was declared dead shortly after it came into being, yet it somehow magically appears to be still with us. What is important is that the final decades of the last century witnessed the almost triumphant institutionalization of the postmodern within the academy, within the publishing and film industries, in the art gallery, and on the theater, concert and opera stage. With his successful institutionalization has come what can only be called the generalizing of postmodernism into a kind of generic, catch-all 
counter-discourse-but, paradoxically, a counter-discourse well on its way to becoming an authoritative ( capital D) Discourse - a doxa, if you will. This is why it is still alive today: it has become canonized, at least in the Western world. It has, therefore, lost a lot of its experimental, radical edge and for this reason has lost its appeal to people looking for the new and different. That said, we may well be on the cusp of something different, something that has been growing out of what I think of as the "late" postmodern moment: I don't know what it will be called, but it will have something to do with the electronic age we live in and the information technology that is changing our world. We are learning that digital is more than just a platform, for instance. Arguably it is changing the very context in which films, for instance, are being made, Distributed and consumed. It is also changing how we tell stories in films, for it challenges the traditional cinematic way of narrating. What we now have is a new compendium of graphic text, still and moving image, sound, and a cursor or interactive touch screen.

This is the equivalent of digital narration what cross-cutting, tracking shots, and close-ups are to narration that privileges the moving image and sound-that is, film (as we once knew it). And because of those navigational devices (the touch screen, the mouse), the new media engage us directly - in an individualized, indeed, personalized manner. Navigation is to interactivity what montage is to film. This also means, of course, that the forward-moving temporal force of film is being replaced by the digital media's interactive, spatial movement. The very conventions of storytelling are changing daily, in other words. Did you know that "Twit Lit" has been born? Last month, Pamela Coles wrote, over a 24-hour period, a short story on Twitter-aided and abetted by hundreds of Tweets from collaborating social network followers, including the famous Canadian novelist Margaret Atwood. The scope made possible by the Internet may well be a real world-changer. Where the early postmodern broke down the barriers between popular and high art forms, the late postmodern breaks down the barriers between what I can only call "worlds," moving from the fictional story world of, for example, the Harry Potter novels, to the real world of social activism. If you go to the "Harry Potter Alliance" website, you'll read this:

Did you ever wish that Harry Potter was real? Well it kind of is. Just as Dumbledore's Army wakes the world up to Voldemort's return, works for equal rights of house elves and werewolves, and empowers its members. Work with partner NGOs in alerting the world to the dangers of global warming, poverty, and genocide. Work with our partners for equal rights regardless of race, gender, and sexuality. Encourage our members to hone the magic of their creativity in endeavoring to make the world a better place. Join our army to make the world a safer, more magical place, and let your voice be heard. Is this late postmodern or is it something new?

Only time will tell. And to answer the second part of your question, I did not really abandon the study of post-modernism, but simply moved on to different aspects of it - specifically its deploying of irony, and then later the ubiquity of adaptation strategies in postmodern art forms of all kinds. My interdisciplinary cultural work on opera comes out of other interests I have developed, but I have also written on postmodern opera, so my interest in postmodernism continues.

\section{The Institutionalization of the Postmodern in the Academy}

You just mentioned "the triumphant institutionalization of the postmodern in the academy." It is really ironic that postmodernism, with its hostile but complicit relationship with modernism, could have ended in the same boat with its modernist 
forefathers, that is, they both ended with a culminated canonization. I say "end" in Arthur Danto's sense: it ended but hasn't been dead yet. We can continue to produce postmodern texts, only to find it has lost its appeal. In view of the similar fates of avantgardism, modernism and postmodernism, does it mean that there would not be any real counter-discourse, since the Establishment could connive at its shocking disturbance for the moment while euthanizing it with institutionalization in the long run? I think it is indeed ironic that postmodernism became as institutionalized as modernism before it, but I also think it is inevitable. As soon as something has been around long enough to establish itself and to become even somewhat canonized - taught in schools, studied in universities, and so on - there is bound to be a reaction against it and a desire for something different and new. You are also right to point to the power of what you call the Establishment which in the case of capitalism, at least, has an amazing power to co-opt or to take over and absorb almost anything, to make it serve its own purposes. It never takes capitalism long to de-radicalize almost anything! We learned that in the West a long time ago! So something new has to come along to challenge it in a new way.

Can you make a general observation about the recent development of postmodernism in the West? I mean, is there still much postmodern writing and criticism published every day? You mentioned the "canonization" of postmodernism. Does it mean that the postmodern methods and values have been widely adopted or assimilated in academic practices (at least), or that they are just acknowledged as another school of the already-said, but not necessarily persuasive, theory? I think postmodern literature is still being written every day-even if something different is also starting to appear (largely in the new media); it is certainly studied in university, as is the theory. The same is true of the postmodern in the visual arts, film, music, video, and so on. Both the art and the study of it are now canonized in the sense that they are all taught in the universities. The inclusive "both / and" way of thinking that I talked about earlier is perhaps less entrenched in our common modes of thinking and working, but it is there as an influence nonetheless. I think the reason postmodern theory and practice have both been absorbed into the Western mainstream is that they were indeed very persuasive: they spoke to a generation of young (and older) people looking for an explanation of the world they were watching around them, a world coming to terms with major social changes - the results of racial, gender and sexual equalization, diasporic migration, multicultural hybridity, and now electronic expansion.

History has always been a favorite topic for Chinese artists, especially for novelists and film-makers. In the 1980s, they were able to manage a critical use of history. But recently, they are more interested in distorting and abusing historical facts (the facts recorded in historical classics of course) rather than carrying out a truthful representation of them. It cannot be denied that these activities show very little critical and political potential as expected by your postmodern poetics. On the contrary, they seem more and more like what Jameson had denounced as cultural farragoes. What do you think has caused such transformation? Pop culture, market economy, dominant ideology, or any other factor? And how about in the West?

I am interested to hear your analysis of how contemporary Chinese artists are using / busing history. In the West, I think it may be different and I'll try to explain how. Then you can tell me how the Chinese artists' ideas compare? Western artists may re-write history, but they do not abuse it or falsify it: they give different versions from different perspectives, however, so that might look like falsifying it, to some people, at least. As you can guess, I disagree with Jameson's assertion that the victory of 
capitalist commodification has meant a loss of what he calls "genuine historicity" that has led to (in his words) a "random cannibalization" of the styles of the past; I think that postmodern fiction by writers like E. L. Doctorow or Toni Morrison have engaged seriously with history and historicity, and have done so (paradoxically) through parody. From its very inception, of course, the novel has been a paradoxical genre that is both fictive and worldly, both inward- and outward-looking. The postmodern variant of it that I once awkwardly called "historiographic metafiction" is even more overtly paradoxical: it is self-consciously fictive (therefore: Metafictional) and yet directly addressing both the historical record and the very act of writing or recording history (hence: historiographic). Here again, as in all postmodern discourses, theory and creative practice overlap. Theorists, like the American Hayden White and Dominick La Capra and the French Paul Veyne and Michel de Certeau, raised the same issues as did the fiction. Among these issues were the facts that, first, both novels and historiography share a narrative form and that, second, both involve the use of language to construct a "world. " The new writers of historiography often refused to hide behind the third-person voice of putative objectivity and instead called attention to the ideological positioning inevitable in any historical account. White called attention to the historian's act of what he dubbed "narrativizing"-and therefore, with the aid of Northrop Frye, made a connection to the literary that was to irritate his historian-colleagues immensely - for a while, until his insights became canonical, at least in some places. The lingering positivist and empiricist assumptions of the modern discipline of history, inherited from the nineteenth century, came under fire from other directions as well, especially from the various modes of poststructuralist theory. Historical events, it was argued, were made into historical facts (that is, they were constructed as fact) by the historian's act of narrativizing or emplotting.

As I see it, the postmodern is not ahistorical, despite Jameson's assertion to the contrary, but is instead obsessed with history. But because poststructuralism and postmodernity together challenged our Western assumptions about totalities and coherent unities, about logic and reason, representation and truth, the kind of "history" with which the postmodern has concerned itself has not been that of the single, neutral, or objective ( capital T) Truth assumed of empirical history in modernity. And this is where Chinese artists may be differing from the Western ones - or maybe not. The Western version of postmodern is not interested in what Lyotard called the "grand narratives" but rather in the "little narratives" of history, the stories that never got told in the modern paradigm. There, traditionally, history was the story of the victors - the kings, the generals, the diplomats, the politicians; in other words, the ones who won the battle that got to tell its story. With the postmodern, it was the peasants, the women, the colonized, and the defeated whose tales also got told. We moved away from the kind of history that Ambrose Bierce satirically defined, in his famous Devil's Dictionary of 1911,in this way: "History, an account, mostly false, of events mostly unimportant, which are brought about by rulers, mostly knaves, and soldiers, mostly fools."But, such cynicism aside, with the postmodern turn, things did change in the discipline of history: even the traditional repository of the official stories itself came under scrutiny: how did documents get into the "archive"? What documents did not make it into the archive for others, later, to study and make into part of the narrative of history to be passed on? In the West, social instigations-from the North American Civil Rights movement to the decolonization of large parts of the world - also, of course, helped provoke this rethinking of history and historiography. It is in this context that postmodernist fiction has deliberately and provocatively 
blurred the seemingly common-sense boundaries between history and fiction, between the documentary and the self-reflexive, between the serious and the playful. Is this what your Chinese writers do? In the nineteenth century, Walter Scott's historical novels sought the legitimizing and authenticating power of actual historical events; in the West, postmodern historiographic metafictions, in contrast, show how historiography and novels are - equally — human constructs, human signifying system. Both render the past in a textualized form. Postmodern fictions are at once narcissistically self-reflexive about their fictionality and yet critically engaged with the real world of history; thus, they have moved to the foreground (and challenged) the conventions and the unacknowledged ideology of these discourses, asking us to question the process by which we represent ourselves and our world to ourselves. It has thus sought to make us more self-aware of the means by which we quite literally make sense of and construct order out of, our experience of our particular culture. Could the Chinese writers be attempting to do the same?

\section{References}

[1] Benhabib, Seyla. Situating the Self: Gender, Community, and Postmodernism in Contemporary Ethics. New York: Routledge, 1992.

[2] Ermarth, Elizabeth Deeds. "Agency in the Discursive Condition." History and Theory 4 (2001) : $34-58$. 